\title{
The Evaluation of Heavy Metals Concentrations in Cempaka Lake, Bangi, Selangor, Malaysia
}

\author{
Muhd. Barzani Gasim, Mohd. Ekhwan Toriman ${ }^{\# 1}$, Amal Barggig ${ }^{\# 2}$, Soaad Mutfah ${ }^{\# 3}$, Norsyuhada \\ Hairoma $^{\$ 4}$, Azizah Endut $\$ 5$ \\ *Faculty of Bio Resources and Food Industries, Universiti Sultan Zainal Abidin, Tembila Campus, 22200 Besut, Terengganu, Malaysia \\ E-mail: barzanigasim@unisza.edu.my \\ ${ }^{\#}$ School of Social, Development and Environmental Studies, Faculty of Social Sciences and Humanities, Universiti Kebangsaan Malaysia, \\ 43600 Bangi, Selangor, Malaysia \\ E-mail: ${ }^{1}$ ikhwan@ukm.edu.my, ${ }^{2}$ barggig55@yahoo.com, ${ }^{3}$ muftah29@yahoo.com
}

${ }^{\$}$ East Coast Environmental Research Institute, Universiti Sultan Zainal Abidin, Gong Badak Campus, 21300 Terengganu, Malaysia E-mail: ${ }^{4}$ nsyuhadahairoma@gmail.com, ${ }^{5}$ enazizah@unisza.edu.my

\begin{abstract}
Seven sampling stations were identified to determine the status of water quality based on heavy metals concentrations in Cempaka Lake, Bandar Baru Bangi within two sampling periods; June 2010 and August 2010. The objective of the study is to determine the seasonal variations in the lake water quality with respect to heavy metals contamination. Seven parameters of heavy metals were analyzed from the water samples, which were collected from the seven different sampling stations at the Cempaka Lake. They are Copper (Cu), Manganese (Mn), Lead (Pb), Zinc (Zn), Iron (Fe), Cadmium (Cd) and Nickel (Ni). The concentrations of these seven heavy metals were determined using inductively coupled plasma-mass spec (ICP-MS) (ELAN 9000). Evaluation of the concentration of heavy metals is carried out based on the NWQS classification. The results are $\mathrm{Cu}$ between 0.0007 to $0.021 \mathrm{mg} / \mathrm{L}, \mathrm{Mn}$ 0.10 to $0.11 \mathrm{mg} / \mathrm{L}, \mathrm{Pb} 0.001$ to $0.002 \mathrm{mg} / \mathrm{L}, \mathrm{Zn} 0.01$ to $0.03 \mathrm{mg} / \mathrm{L}, \mathrm{Fe} 1.03$ to $4.41 \mathrm{mg} / \mathrm{L}, \mathrm{Cd} 0.0001$ to $0.0002 \mathrm{mg} / \mathrm{L}$ and $\mathrm{Ni} 0.0013$ to 0.014 $\mathrm{mg} / \mathrm{L}$. The data obtained from this study were analyzed statistically using the one-way ANOVA, to determine the existence of the relationship based on partial and temporal conditions of the each heavy metal. The results of the analysis of the seven heavy metals in the seven sampling stations found that the concentration of heavy metals is relatively low. Only Fe has high content and fall into class IV, followed by Mn in class II while the other five heavy metals remain in class I.
\end{abstract}

Keywords - Cempaka lake; heavy metals concentration; inductively coupled plasma-mass spec; seasonal variations; one-way ANOVA

\section{INTRODUCTION}

Heavy metal pollution is a major environmental problem in the world, and usually, it is associated with areas of intensive heavy industry [1]-[3]. Heavy metal pollution can be either natural or anthropogenic origin; natural sources could be comes from the mineralogy and the weathering process while anthropogenic sources comes from mining, disposal of untreated and partially treated effluents contain toxic metals, fertilizer and pesticides [4]. Heavy metals contamination in the river is one of the major quality issues in many fast-growing cities because maintenance of water quality and sanitation infrastructure did not increase along with population and urbanization growth especially in the developing countries [5]-[7].
Smaller amounts of many other metals such as nickel and cadmium are traces in the road runoff and exhaust. About half of the zinc and copper contributed to the environment is from urbanization as well from automobile brakes that release copper [8]. Rivers in urban areas have also been associated with water quality problems because contamination of toxic elements from the nearby industries and communities. As heavy metals are non-biodegradable and accumulative in nature, the elevated metal emissions and their deposition over time can lead to anomalous enrichment and the contamination of the surface environment [9].

Cempaka Lake, Bangi is chosen as a focus in this study as a function of recreational area. It contains a lake garden and picnic gazebos. This lake is considered as an opened lake, whereas the water recharges only based on rainfall and small 
rivers. The lake becomes a place which attracts insects such as mosquitoes and contains fishes. With an increase of population growth, the population around the Bangi area will produce more domestic and other types of pollution. Some pollution sources surrounding the lake were identified from the commercials, hospitals, clinics, residential as typical for urban stream [10].

The undesirable activities and unscientific utilization of resources from the lakes have caused various undesirable environmental problems, thus threatening the biodiversity that should be sustained by it [11]. Describe the impact of acid mine from coal mine in South Sumatera, Indonesia [12]. It is again significant to note that these species-rich aquatic ecosystems are capable of self-maintaining. However, the delicate equilibrium is sensitive to external stimuli such as the human activities promoted by socio-economic goals. Exercising a control on the existing anthropogenic activities is necessary to sustain these socio-economically and bioaesthetically which are important for aquatic ecosystems. The fresh water resource which is facing a faster rate of deterioration of the water quality is now a global problem [13]-[18]. The results can also be used to determine if a particular stretch of water is proposed as healthy [19]. The objective of the study is to determine the seasonal variations of heavy metals contamination in the Cempaka Lake water quality.

\section{MATERIAL AND METHOD}

Heavy metals including both the essential and nonessential elements have a particular significance in ecotoxicology, since they are highly persistent and have all the potential to be toxic to living organisms. There are several sources of pollution that are scattered around the lake such as petrol pump stations, medical clinics, restaurants, government offices, workshops, housing will eventually discharge their wastewater to the Cempaka Lake. The elements that are generally determined in drinking water include copper $(\mathrm{Cu})$, Manganese $(\mathrm{Mn})$, lead $(\mathrm{Pb})$, Zinc $(\mathrm{Zn})$, iron $(\mathrm{Fe})$, Cadmium $(\mathrm{Cd})$ and Nickel $(\mathrm{Ni})$. Seven sampling stations were chosen from the surrounding the lake (station 1 to station 7) as shown in Fig. 1. Station 1 was located at the inlet area of the lake, four sampling stations (station 2 to station 5) in the surroundings of the lake and station 6 was in the center and the last station, station 7 was located at the outlet of the lake. The water samples were taken using polyethylene bottles, which had been soaked and cleaned before the sampling. After the collection, the water samples were immediately placed into ice boxes and processed for analysis in the laboratory. Heavy metals were determined using inductively coupled plasma-mass spec (ICP-MS) (ELAN 9000). Evaluation of the concentration of heavy metals is carried out based on the NWQS classification. Three replications of samples were taken randomly at each station. The data obtained from this study were analyzed statistically using the one-way ANOVA to determine the existence of the relationship among the parameters. The data set was separately examined for two sampling periods which are statistically significant. Statistically, significant differences between groups were assessed using Microsoft excel and the correlation between related parameters was performed. 


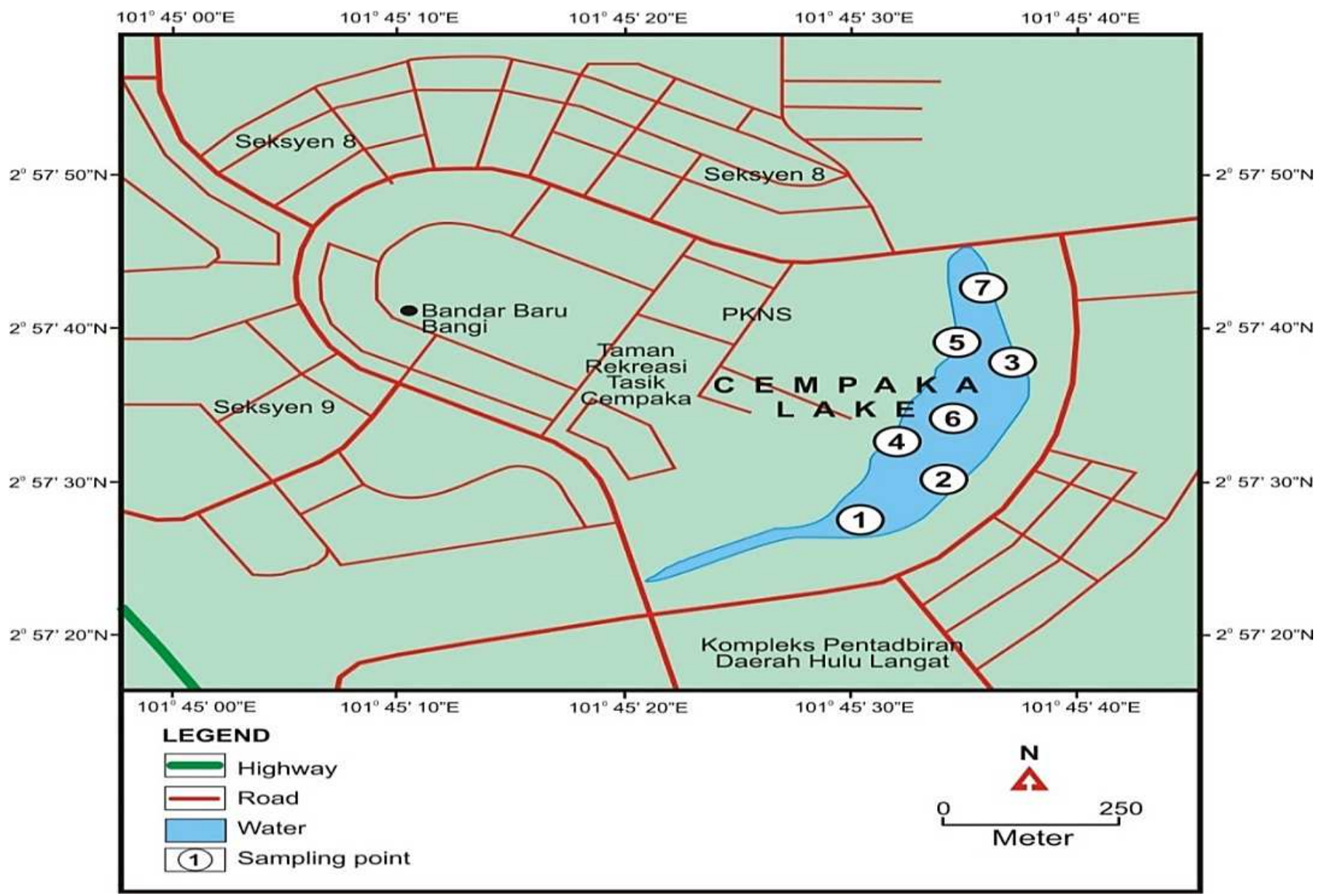

Fig. 1 Location of seven water sampling stations in Cempaka Lake

\section{RESULTS AND DISCUSSION}

Seven of heavy metals were analyzed from the water samples which were collected from the seven sampling stations in the Cempaka Lake such as Copper $(\mathrm{Cu})$, Manganese (Mn), Lead ( $\mathrm{Pb})$, Zinc ( $\mathrm{Zn})$, Iron (Fe), Cadmium $(\mathrm{Cd})$ and Nickel $(\mathrm{Ni})$. Each of them will be described as follows.

\section{A. Copper $(\mathrm{Cu})$}

The range of $\mathrm{Cu}$ during the first sampling was from 0.0001 to $0.1 \mathrm{mg} / \mathrm{L}$ with an average of $0.021 \mathrm{mg} / \mathrm{L}$, which the highest $(0.1 \mathrm{mg} / \mathrm{L})$ was recorded at St. 5 and the lowest $(0.0001 \mathrm{mg} / \mathrm{L})$ was recorded at St. 7. The range of Cu during the second sampling was from 0.0002 to $0.002 \mathrm{mg} / \mathrm{L}$ with an average of $0.0007 \mathrm{mg} / \mathrm{L}$, where the highest $(0.002 \mathrm{mg} / \mathrm{L})$ was recorded at St. 4 and the lowest $(0.0002 \mathrm{mg} / \mathrm{L})$ was recorded at St. 5, 6 (Fig. 2a). The average of two samplings of $\mathrm{Cu}$ in the study area was $(0.017 \mathrm{mg} / \mathrm{L} \pm 0.005)$ as shown in Fig. $2 b$.

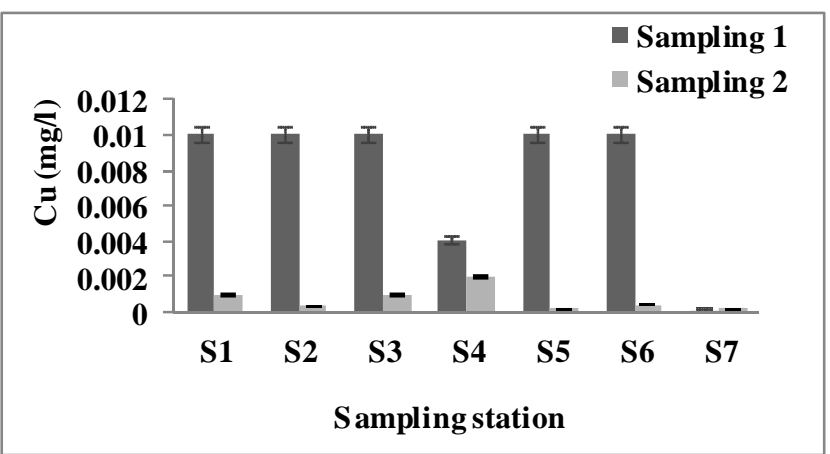

Fig. 2a Distribution of Copper $(\mathrm{Cu})$ values between two samplings

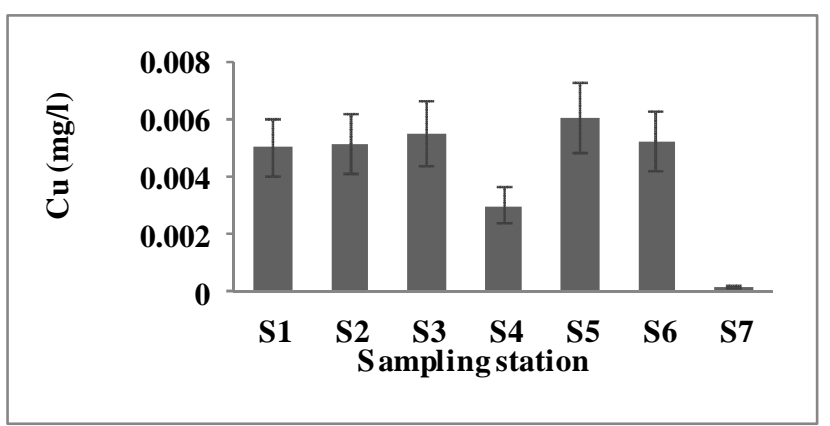

Fig. 2b Mean copper $(\mathrm{Cu})$ values at seven sampling stations

\section{B. Manganese (Mn)}

The range of Mn during the first sampling was from 0.08 to $0.13 \mathrm{mg} / \mathrm{L}$ with an average of $0.10 \mathrm{mg} / \mathrm{L}$, where the 
highest $(0.13 \mathrm{mg} / \mathrm{L})$, was recorded at station 5 and the lowest $(0.08 \mathrm{mg} / \mathrm{L})$ was recorded at station 7 . The range of $\mathrm{Mn}$ during the second sampling was from 0.10 to $0.12 \mathrm{mg} / \mathrm{L}$ with an average of $0.11 \mathrm{mg} / \mathrm{L}$, which the highest $(0.12 \mathrm{mg} / \mathrm{L})$ was recorded at station 4 and the lowest $(0.10 \mathrm{mg} / \mathrm{L})$ was recorded at stations 1 and 7 (Fig. 3a). The average of two samplings of $\mathrm{Mn}$ in the study area was $(0.12 \mathrm{mg} / \mathrm{L} \pm 0.007)$ as shown in Fig. $3 b$.

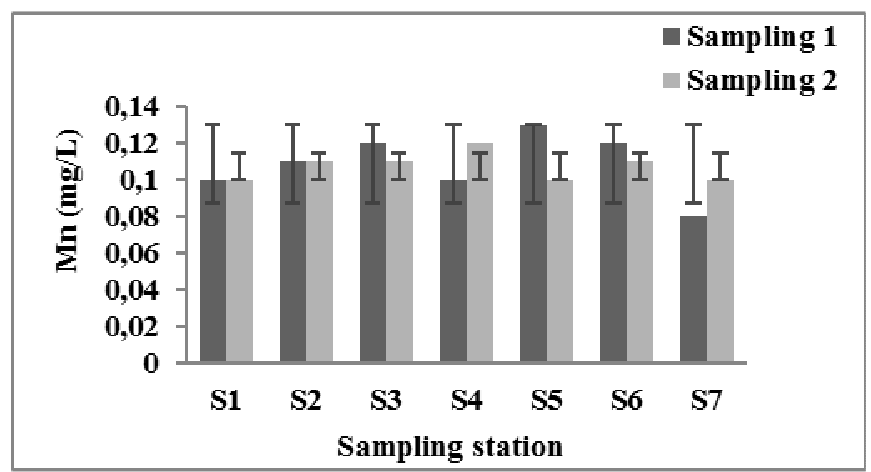

Fig. 3a Distribution of Manganese (Mn) values between two samplings

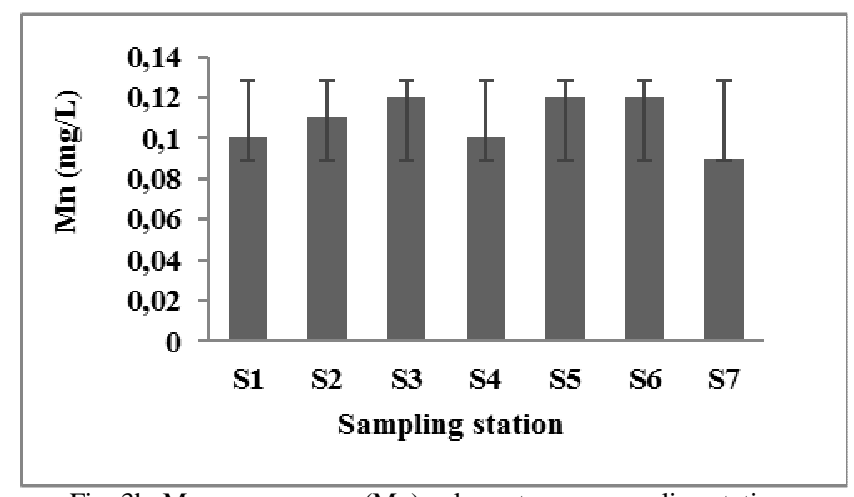

Fig. 3b Mean manganese (Mn) values at seven sampling stations

\section{Lead $(P b)$}

The range of $\mathrm{Pb}$ during the first sampling was from 0.0001 to $0.01 \mathrm{mg} / \mathrm{L}$ with an average of $0.002 \mathrm{mg} / \mathrm{L}$, which the highest $(0.01 \mathrm{mg} / \mathrm{L})$ was recorded at station 1 and the lowest $(0.0001 \mathrm{mg} / \mathrm{L})$ was recorded at station 7 . The range of $\mathrm{Pb}$ during the second sampling was from 0.0001 to 0.001 $\mathrm{mg} / \mathrm{L}$ with an average of $0.001 \mathrm{mg} / \mathrm{L}$, where the highest $(0.001 \mathrm{mg} / \mathrm{L})$ was recorded at station 1 and the lowest $(0.0001 \mathrm{mg} / \mathrm{L})$ was recorded at station 6 (Fig. 4a). The average of two samplings of $\mathrm{Pb}$ in the study area was $(0.001$ $\mathrm{mg} / \mathrm{L} \pm 0.001$ ) as shown in Fig. $4 \mathrm{~b}$.

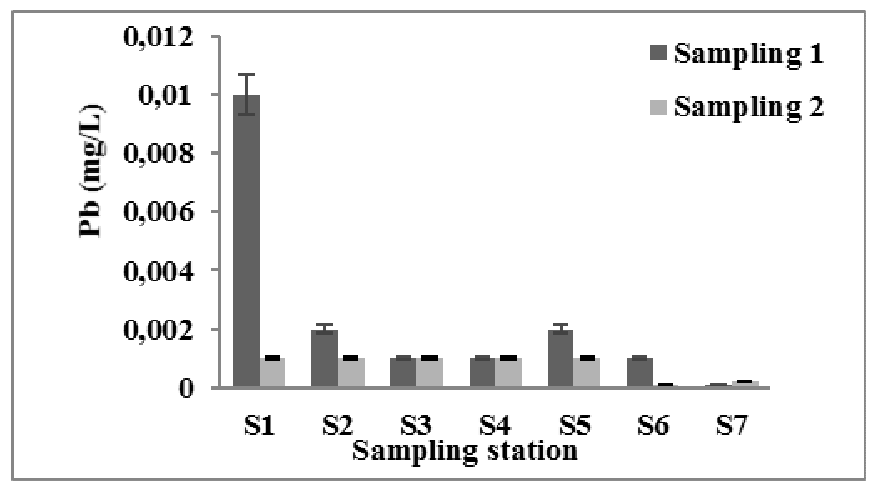

Fig. 4a Distribution of Lead $(\mathrm{Pb})$ values between two samplings

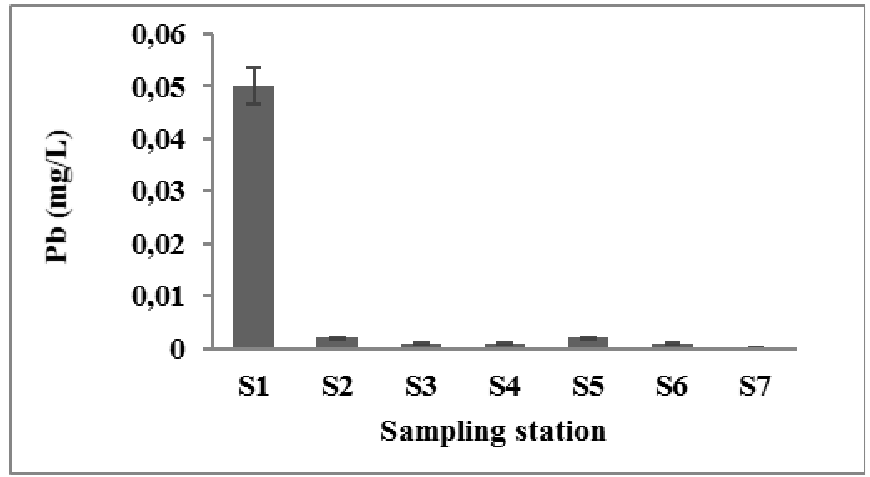

Fig. 4b Mean lead $(\mathrm{Pb})$ values at seven sampling stations

D. Zinc $(\mathrm{Zn})$

The range of $\mathrm{Zn}$ during the first sampling was from 0.008 to $0.04 \mathrm{mg} / \mathrm{L}$ with an average of $0.03 \mathrm{mg} / \mathrm{L}$, where the highest $(0.04 \mathrm{mg} / \mathrm{L})$ was recorded at station 3 and the lowest $(0.008 \mathrm{mg} / \mathrm{L})$ was recorded at station 7 . The range of $\mathrm{Zn}$ during the second sampling was from 0.01 to $0.04 \mathrm{mg} / \mathrm{L}$ with an average of $0.01 \mathrm{mg} / \mathrm{L}$, which the highest $(0.04 \mathrm{mg} / \mathrm{L})$ was recorded at station 3 and the lowest $(0.01 \mathrm{mg} / \mathrm{L})$ was recorded at station 7 (Fig. 5a). The average of two samplings of $\mathrm{Zn}$ in the study area was $(0.023 \mathrm{mg} / \mathrm{L} \pm 0.01)$ as shown in Fig. 5b.

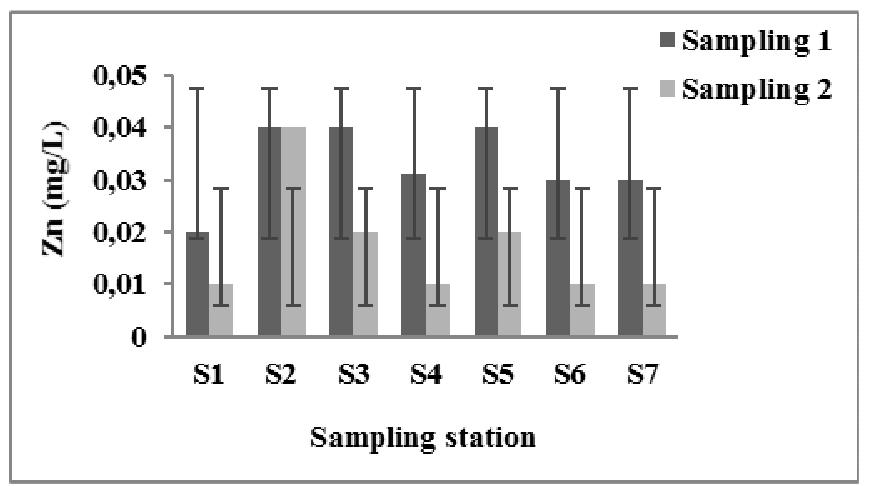

Fig. 5a Distribution of Zinc (Zn) values between two samplings

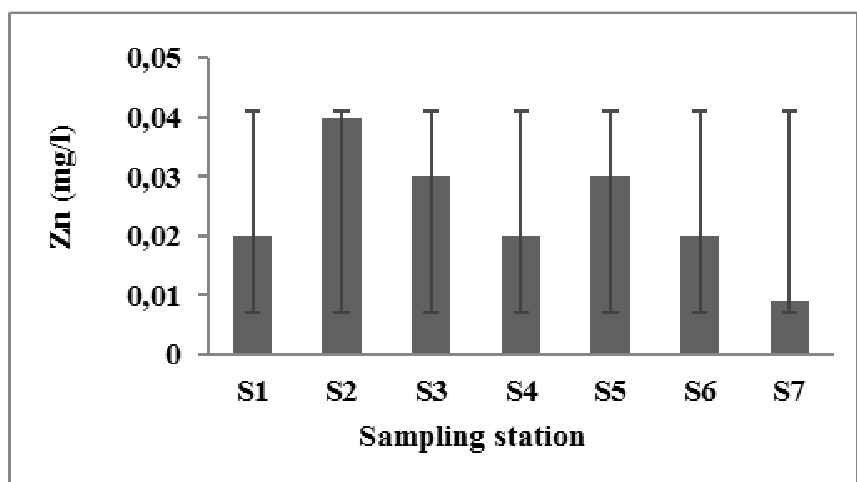

Fig. 5b Mean zinc $(\mathrm{Zn})$ values at seven sampling stations

\section{E. $\operatorname{Iron}(\mathrm{Fe})$}

The range of Fe during the first sampling was from 0.06 to $2.00 \mathrm{mg} / \mathrm{L}$ with an average of $1.03 \mathrm{mg} / \mathrm{L}$, which the highest $(2.00 \mathrm{mg} / \mathrm{L})$, was recorded at station 2 and the lowest $(0.06 \mathrm{mg} / \mathrm{L})$ was recorded at station 7 . The range of $\mathrm{Fe}$ during the second sampling was from 2.25 to $6.00 \mathrm{mg} / \mathrm{L}$ with an average of $4.41 \mathrm{mg} / \mathrm{L}$, where the highest $(6.00 \mathrm{mg} / \mathrm{L})$ was recorded at station 2 and the lowest $(2.25 \mathrm{mg} / \mathrm{L})$ was recorded at station 7 (Fig. 6a). The average of two samplings 
of $\mathrm{Fe}$ in the study area was $(2.72 \mathrm{mg} / \mathrm{L} \pm 2.36)$ as shown in Fig. 6 b.

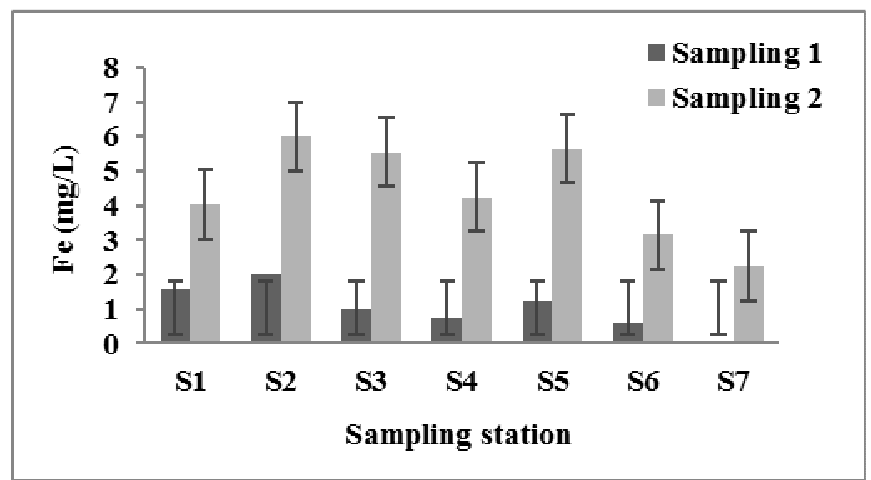

Fig. 6a Distribution of Iron (Fe) values between samplings Fig. 1

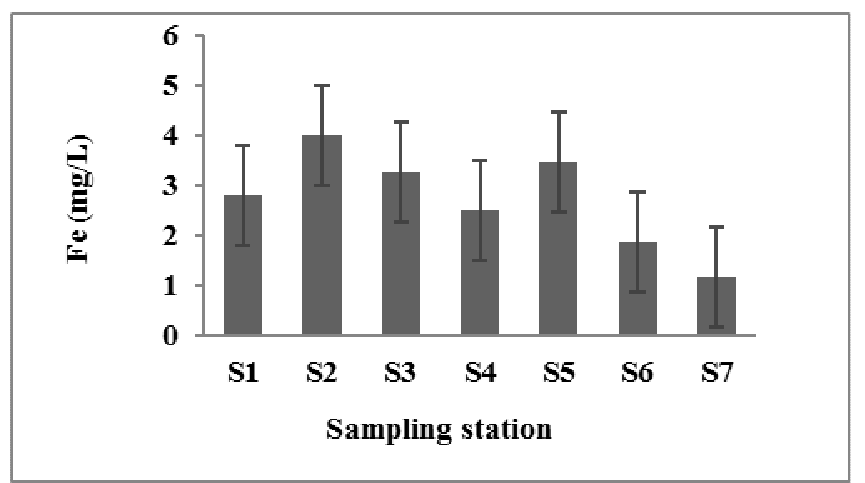

Fig. 6b Mean iron (Fe) values at seven sampling stations

\section{F. Cadmium (Cd)}

The range of $\mathrm{Cd}$ during the first sampling was from 0.0001 to $0.0004 \mathrm{mg} / \mathrm{L}$ with an average of $0.0002 \mathrm{mg} / \mathrm{L}$, where the highest $(0.0004 \mathrm{mg} / \mathrm{L})$ was recorded at station 3 and the lowest $(0.0001 \mathrm{mg} / \mathrm{L})$ was recorded at station 7 . The range of $\mathrm{Cd}$ during the second sampling was 0.0001 to $0.0002 \mathrm{mg} / \mathrm{L}$ with an average of $0.0001 \mathrm{mg} / \mathrm{L}$, which the highest $(0.0002 \mathrm{mg} / \mathrm{L})$ was recorded at station 4 and the lowest $(0.0001 \mathrm{mg} / \mathrm{L})$ was recorded at station 7 (Fig. 7a). The average of two samplings of $\mathrm{Cd}$ in the study area was $(0.0001 \mathrm{mg} / \mathrm{L} \pm 0)$ as shown in Fig. $7 \mathrm{~b}$.

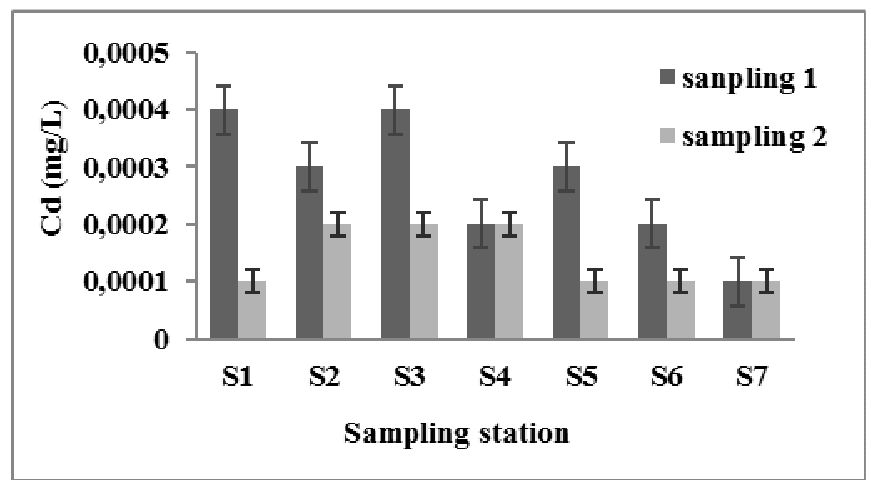

Fig. 7a Distribution of Cadmium (Cd) values between two samplings

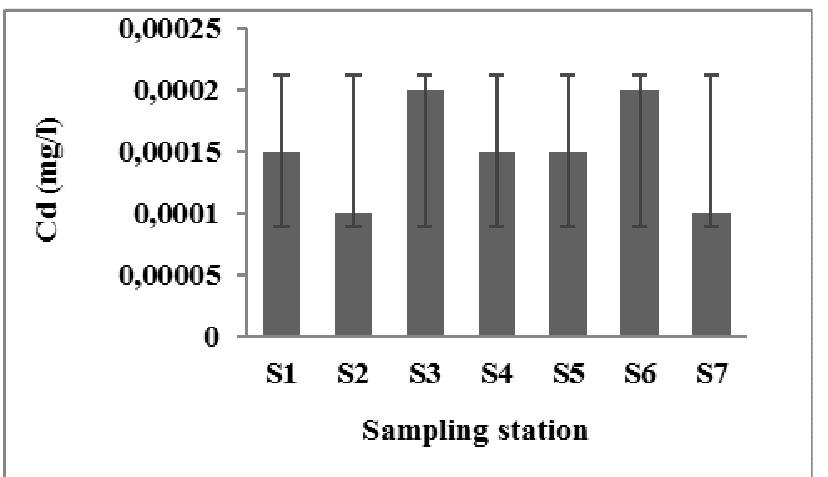

Fig. $7 b$ Mean cadmium (Cd) values at 7 sampling stations

\section{G. Nickel (Ni)}

The range of $\mathrm{Ni}$ during the first sampling was from 0.0008 to $0.002 \mathrm{mg} / \mathrm{L}$ with an average of $0.0013 \mathrm{mg} / \mathrm{L}$, which the highest $(0.002 \mathrm{mg} / \mathrm{L})$ was recorded at station 2 and the lowest $(0.0008 \mathrm{mg} / \mathrm{L})$ was recorded at station 7 . The range of $\mathrm{Ni}$ during the second sampling was 0.01 to 0.02 $\mathrm{mg} / \mathrm{L}$ with an average of $0.014 \mathrm{mg} / \mathrm{L}$, where the highest $(0.02 \mathrm{mg} / \mathrm{L})$ was recorded at station 3 and the lowest $(0.01$ $\mathrm{mg} / \mathrm{L}$ ) was recorded at station 7 (Fig. 8a). The average of two sampling of $\mathrm{Ni}$ was $(0.007 \mathrm{mg} / \mathrm{L} \pm 0.006)$ as shown in Fig. 8b.

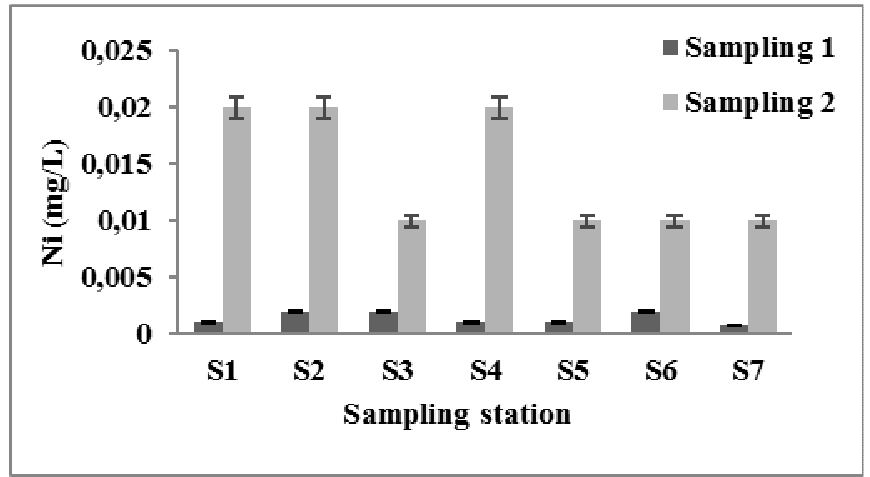

Fig. 8a Distribution of (Ni) values between two samplings

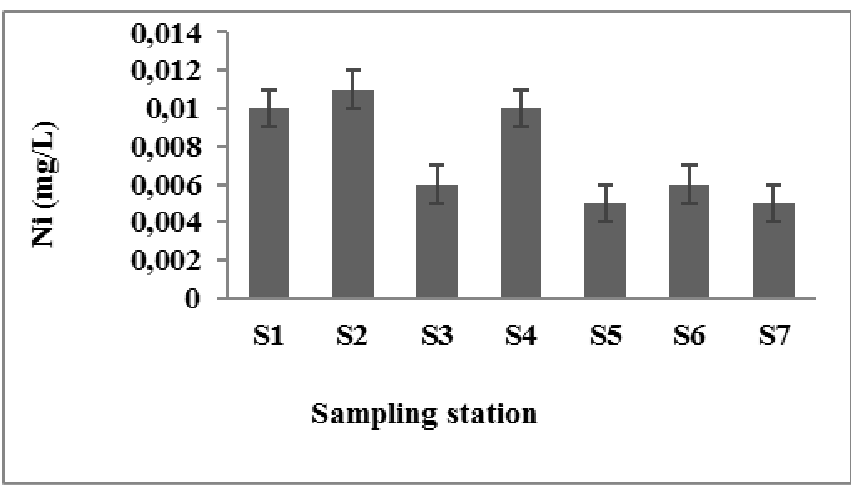

Fig. 8b Mean Nickel (Ni) values at 7 sampling stations

The explanation of statistical analysis of the seven of heavy metals will be explain as follows.

\section{A. Copper}

Statistical analysis showed there were no significant differences between sampling stations and between sampling times $(p>0.05 ; p<0.05)$. Based on the NWQS, the level of $\mathrm{Cu}$ is classified as Class I. $\mathrm{Cu}$ contributed to the environment 
through vehicles. Oil is another pathway by which metal enters the environment via the road surface and the metal becomes bound to the surfaces of road dust or other particles.

\section{B. Manganese}

Statistical analysis showed that there were no significant differences between stations and between sampling times ( $p>0.05 ; p>0.05$ ). Based on the NWQS, the level of Mn is classified as Class II. With respect to the Mn metal, the study reveals that there are expected additions of quantities of industrial effluents and anthropogenic wastes that are particularly associated with the water streams in the lake.

\section{Lead}

Statistical analysis showed that there were no significant differences of $\mathrm{Pb}$ between stations and sampling times $(\mathrm{p}>$ 0.05; $\mathrm{p}>0.05$ ). Based on the NWQS, the level of $\mathrm{Pb}$ in the study area is classified as Class I. Pb deposited in parking lots and roads can be carried by surface runoff that flows into the lakes. The presence of $\mathrm{Pb}$ can be observed not only in the area density of vehicles, but also the atmosphere that falls with rain water and transported to aquatic sediments [21] effectively than the surface area. There is an increasing problem of heavy metal contamination during a surface runoff in the area city. However, the $\mathrm{Pb}$ values in this study are not high different compared to the value obtained by [20] based on their study in Tasik Chini (0.0016 to $0.0034 \mathrm{mg} / \mathrm{L})$.

\section{Zinc}

Statistical analysis showed that there were significant difference between sampling stations and between sampling times (ANOVA, $\mathrm{p}<0.05$; $\mathrm{p}<0.05$ ). Based on the NWQS, the level of $\mathrm{Zn}$ in the study area is classified as Class I. High concentration of $\mathrm{Zn}$ indicates an increase of pollution load due to the movement of agricultural ashes, industrial effluents and anthropogenic wastes [9] or from vehicle exhausts, oil lubricants, automobile parts and the corrosion of building materials. However, the $\mathrm{Zn}$ values of the lake in this study are slightly higher compared to [20] based on their study in Tasik Chini (0.005 to $0.006 \mathrm{mg} / \mathrm{L})$.

\section{E. Iron}

Statistical analysis showed that there were significant differences in the mean Fe levels between stations and between sampling times $(\mathrm{p}<0.05 ; \mathrm{p}<0.05)$. Based on the NWQS, the level of Fe in the study area is classified as Class IV. The highest concentration of $\mathrm{Fe}$ may be due to the discharge of industrial wastes into the water body [1]. However, the Fe values of the lake in this study are higher compared to the value obtained by [20] based on their study in Tasik Chini (0.32 to $1.02 \mathrm{mg} / \mathrm{L})$.

\section{F. Cadmium}

The statistical analysis showed that there were no significant differences between the seven sampling stations, but significant differences between the sampling times (ANOVA, $\mathrm{p}>0.05 ; \mathrm{p}<0.05$ ) respectively. Based on the NWQS, the level of $\mathrm{Cd}$ in the study area is classified as Class I. The results of $\mathrm{Cd}$ are low during the second sampling, but high during the first sampling, this may be due to the presence of $\mathrm{Cd}$ in the dust and deposited in the lake. The presence of $\mathrm{Cd}$ the atmosphere is usually caused by burning of fossil fuels in vehicles, industrial activities and construction activities very rapidly in the vicinity of the basin. However, the $\mathrm{Cd}$ values of the lake in this study are about the same to the value obtained by [20] based on their study in Tasik Chini (0.0003 to $0.0004 \mathrm{mg} / \mathrm{L})$.

\section{G. Nickel}

Statistical analysis showed that were no significant differences in the mean contents of $\mathrm{Ni}$ in the seven sampling stations, but significant differences between sampling times (ANOVA, $\mathrm{p}>0.05 ; \mathrm{p}<0.05$ ) respectively. Based on the NWQS, the level of Ni in the study area is classified as Class I. However, the Ni values of the lake in this study are lower compared to the value obtained by [1] in the study of Ganga river of India which was between 0.012 to $0.37 \mathrm{mg} / \mathrm{L}$.

\section{CONCLUSION}

The results of the analysis of the seven heavy metals in the seven sampling stations found that the concentration of heavy metals is relatively low. Only Fe has high content and in class IV, followed by Mn in class II. Despite the relative distribution of heavy metals present in general are in Class I, but likely their concentration will be increased in the future in line with an increase in human activity.

Based on the statistical analyses show that $\mathrm{Zn}$, Fe were significantly different between sampling stations and sampling times, $\mathrm{Cd}$ and $\mathrm{Ni}$ have significantly different only during sampling times. But three heavy metals namely $\mathrm{Pb}$, $\mathrm{Mn}$ and $\mathrm{Cu}$ have no significant during sampling times and stations.

Monitoring should be carried out from time to time of the waste waters that enter into Lake Cempaka, to trace and control new contamination as well to identify the sources, especially those that can have a direct impact on existing aquatic life in the lake.

\section{ACKNOWLEDGMENT}

The authors would also like to thank to East Coast Environmental Research Institute (ESERI, UniSZA) for the use of their research laboratory facilities. The authors would like to thank Assoc. Prof. Dr. Azizah Endut and Dr. Fathurrahman Lananan for the willingness to read and editing this manuscript.

\section{REFERENCES}

[1] D. Kar, P. Sur, S. K. Mandal, T. Saha, and R. K. Kole, "Assessment of heavy metal pollution in surface water," International Journal of Environmental Science and Technology, vol. 5, pp. 119-124, Dec. 2008.

[2] M. W. Akhtar, M. Paramasivam, M. Ganguly, S. Purkait, and D. Sengupta, "Assessment and occurrence of various heavy metals in surface water of Ganga river around Kolkata: A study for toxicity and ecological impact," Environmental Monitoring and Assessment, vol. 160, pp. 207-213, Jan. 2010.

[3] W. Z. Tang, B. Q. Shan, H. Zhang, and Z. P. Mao, "Heavy metal sources and associated risk in response to agricultural intensification in the estuarine sediments of Chaohu Lake Valley, East China," Journal of Hazardous Materials, vol. 176, pp. 945-951, Apr. 2010.

[4] R. Reza and G. Singh, "Heavy metal contamination and its indexing approach for river water," International Journal of Environment Science and Technology, vol. 7, pp. 785-792, Sep. 2010.

[5] N. Ahmad, M. S. Jaafar, and M. S. Alsaffar, "Study of radon concentration and toxic elements in drinking and irrigated water and its implications in Sungai Petani, Kedah, Malaysia," Journal of 
Radiation Research and Applied Sciences, vol. 8, pp. 294-299, Jul. 2015.

[6] S. Whitmee, A. Haines, C. Beyrer, F. Boltz, A. G. Capon, B. F. D. S Dias, A. Ezeh, H. Frumkin, P. Gong, P. Head, R. Horton, G. M. Mace, R. Marten, S. S. Myers, S. Nishtar, S. A. Osofsky, S. K. Pattanayak, M. J. Pongsiri, C. Romanelli, A. Soucat, J. Vega, and D. Yach, "Safeguarding human health in the Anthropocene epoch: report of The Rockefeller Foundation-Lancet Commission on planetary health," The Lancet, vol. 15, pp. 1973-2028, Nov. 2015.

[7] M. K. Ahmad, S. Islam, S. Rahman, M. R. Haque, and M. M. Islam, "Heavy metals in water, sediment and some fishes of Buriganga River, Bangladesh," International Journal of Environmental Research, vol. 4, pp. 321-332, Apr. 2010.

[8] A. Stéphane, S. Jörg, B. Gérard, and J. M. Jouanneau, "Fifty-year sedimentary record of heavy metal pollution $(\mathrm{Cd}, \mathrm{Zn}, \mathrm{Cu}, \mathrm{Pb})$ the Lot River reservoirs (France),' Environmental Pollution, vol. 132, pp. 413-426, Dec. 2004

[9] Škrbic, B. and N. Đuriśić-Mladenović, "Chemometric Interpretation of Heavy Metal Patterns in Soils Worldwide". Chemosphere, 80, 1360-1369. http://dx.doi.org/10.1016/j.chemosphere.2010.06.010

[10] K. Sekabira, O. H. Origa, T. A. Basamba, G. Mutumba, and E. Kakudidi, "Assessment of heavy metal pollution in the urban stream sediments and its tributaries," International Journal of Environment Science and Technology, vol. 7, pp. 435-446, Jun. 2010.

[11] C. Copat, F. Bella, M. Castaing, R. Fallico, S. Sciacca, and M. Ferrante, "Heavy metals concentrations in fish from Sicily (Mediterranean Sea) and evaluation of possible health risks to consumers," Bulletin of Environmental Contamination and Toxicology, vol. 88, pp. 78-83, Jan. 2012.

[12] M. G. Abdullahi, M. K. A. Kamarudin, M. E. Toriman, M. B. Gasim, A. Endut, and I. Garba, "Assessment of natural groundwater recharge in Terengganu, Malaysia," International Journal on Advanced Science, Engineering and Information Technology, vol. 6, pp. 781786, Oct. 2016.

[13] M. R. Mahananda, B. P. Mohanty, and N. R. Behera, "Physicochemical analysis of surface and ground water of Bargarh district, Orissa, India," International Journal of Research and Reviews in Applied Sciences, vol. 2, pp. 284-295, 2010.
[14] H. Zeng and J. Wu, "Heavy metal pollution of lakes along the midlower reaches of the Yangtze River in China: Intensity, sources and spatial patterns," International Journal of Environmental Research Public Health, vol. 10, pp. 793-807, Feb. 2013.

[15] X. Jiang, W. W. Wang, S. H. Wang, B. Zhang, and J. C. Hu, "Initial identification of heavy metals contamination in Taihu Lake, a eutrophic lake in China," Journal of Environmental Sciences, vol. 24 pp. 1539-1548, Sep. 2012.

[16] M. K. A. Kamarudin, M. E. Toriman, M. H. Rosli, H. Juahir, A. Azid, S. F. Mohamed Zainuddin, N. A. Abdul Aziz, and W. N. A. Sulaiman, "Analysis of meander evolution studies on effect from land use and climate change at upstream reach of Pahang River, Malaysia," Mitigation and Adaptation Strategies for Global Change, vol. 20, pp. 1319-1334, Dec. 2015.

[17] M. K. A. Kamarudin, M. Idris, and M. E. Toriman, "Analysis of Leptobarbus hoevenii in control environment at natural lakes," American Journal of Agricultural and Biological Science, vol. 8, pp. 142-148, 2013.

[18] A. A. Mohamed, S. A. Rahim, D. A. Aitman, and M. K. A. Kamarudin. "Analysis of seasonal soil organic carbon content at Bukit Jeriau Forest, Fraser Hill, Pahang," Malaysian Journal of Analytical Sciences, vol.20, pp. 452-460, 2016.

[19] Q. Sui, X. Cao, S. Lu, W. Zhao, Z. Qiu, and G. Yu, "Occurrence, sources and fate of pharmaceuticals and personal care products in the groundwater: A review," Emerging Contaminants, vol. 1, pp. 14-24, Nov. 2015.

[20] I. Mushrifah, M. Shuhaimi-Othman, A. Ahmad, and E. C. Lim, "Seasonal influence on water quality and heavy metals concentration in Tasik Chini, Peninsular Malaysia," in Proc. TAAL'07, 2007, p. 300.

[21] N. A. Wahab, M. K. A. Kamarudin, M. B. Gasim, R. Umar, F. M. Ata, and N. H. Sulaiman, "Assessment of total suspended sediment and bed sediment grains in upstream areas of Lata Berangin, Terengganu," International Journal on Advanced Science, Engineering and Information Technology, vol. 6, pp. 757-763, Oct. 2016 